\title{
First record of Myzus persicae (Sulzer, 1776) in Eucalyptus urophylla S. T. Blake
}

\author{
Primeiro registro de Myzus persicae (Sulzer, 1776) \\ em Eucalyptus urophylla S. T. Blake
}

\section{Estela Rosana Durães Vieira ${ }^{1 *}$, Marcus Alvarenga Soares', Enilson de Barros Silva', Sebastião Lourenço Assis Júnior ${ }^{1}$, Gabriel Alves Barroso ${ }^{1}$}

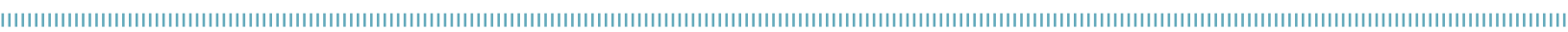

\begin{abstract}
Insect pests are limiting factors to the expansion of Eucalyptus spp. plantations in Brazil. Aphids of the species Myzus persicae (Sulzer, 1776) (Hemiptera: Aphididae) are a key pests in different crops and may negatively affect the growth, development and survival of plants. This paper reports the first record of $M$. persicae in seedlings of Eucalyptus urophylla grown in a greenhouse in Diamantina, Minas Gerais state, Brazil. This finding suggests the implementation of an integrated management program for this aphid, in order to prevent it from becoming a pest in Eucalyptus.
\end{abstract}

KEYWORDS: Insecta; seedlings; aphids.
RESUMO: Insetos considerados pragas são fatores limitantes à expansão da eucaliptocultura no Brasil. Os pulgóes da espécie Myzus persicae (Sulzer, 1776) (Hemiptera: Aphididae) podem ser pragas-chave em diversas culturas, pois afetam negativamente o crescimento, o desenvolvimento e a sobrevivência das plantas. Este trabalho relata o primeiro registro de ocorrência de $M$. persicae em mudas de Eucalyptus urophylla conduzidas em casa de vegetação no município de Diamantina, MG, Brasil. Essa constatação sugere a implantação de um programa de manejo integrado para tal afídeo, a fim de evitar que ele se torne praga para a cultura do eucalipto.

PALAVRAS-CHAVE: Insecta; mudas; afídeos. 
Reforestation in the past decades contributed to the migration of phytophagous insects to monocultures of exotic species and may become one of the barriers to the expansion of Eucalyptus spp. plantations in Brazil (Menezes et al., 2012). Aphids are among the most economically important groups of insects, with approximately 4,000 described species (CARDOso, 2001). These insects cause direct and indirect damage to plants due to their feeding habit (sap-sucking), which may result in leaf damage (TARIQ et al., 2012). They may cause direct damage (e.g., when they are feeding on plants, affecting the apical regions, which may result on plants death) (QueIROz et al., 2010) or indirect (e.g., when they transmit viruses to plants). Furthermore, aphids may promote the spread of sooty mold due to the excretion of honeydew (Leite et al., 2011).

The aphid Myzus persicae (Sulzer, 1776) (Hemiptera: Aphididae) has been found in 50 families, including 500 species of host plants distributed worldwide (PEÑA-MARTINES, 1992). In Brazil it is popularly known as pulgão-verde (literally green-aphid) and often occurs in cruciferous, cucurbits and solanaceous plants, being considered a key pest of cotton, tobacco, papaya, potato, tomato, eggplant and pepper plantations (GALlo et al., 2002). In Diamantina region (Minas Gerais state, Brazil), this aphid has been found attacking cabbage [Brassica sylvestris (L.) Mill.] and sweet potato [Ipomoea batatas (L.) Lam.] (CASTro et al., 2013).

The objective of this study was to report the first occurrence of M. persicae (Sulzer, 1776) in Eucalyptus urophylla $S$. T. Blake seedlings grown in a greenhouse in Diamantina.
The aphids were found in E. urophylla seedlings that were being grown in a greenhouse at the Departamento de Agronomia of Universidade Federal dos Vales do Jequitinhonha e Mucuri (UFVJM), in Diamantina. The seedlings was being grown in hydroponic system with compressed air for aeration and nutrient solution as proposed by CLARK (1975), prepared with pure reagents. The mean temperature and relative humidity during the experiment at the greenhouse were $26.6^{\circ} \mathrm{C}$ and $46 \%$, respectively.

The presence of M. Persicae (winged and aptera forms) was found 30 days after the installation of the seedlings in the greenhouse, at the three layers of the seedlings canopy (upper, middle and basal leaves). The leaves that were being attacked by these aphids showed necrotic spots. The presence of sooty mold was also observed below the leaves. Although this was the first finding of this species of aphid in Eucalyptus ssp., there are records of the occurrence of $M$. persicae in other species of Myrtaceae. These records include the genera Callistemon spp. and Calothamnus spp. (Blackman; Eastop, 2006). In addition, there are records of aphids in Eucalyptus seedlings, but they were not identified (Privet et al., 2009).

This record is very important, and justifies the inclusion of this insect in integrated pest management programs of Eucalyptus spp., in order to prevent that M. persicae becomes a pest in this crop. This aphid has a large host range in the field and the presence of extensive areas planted with E. urophylla in the Minas Gerais state may contribute to a possible adaptation.

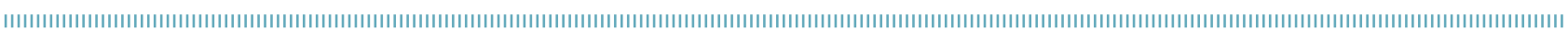
REFERENCES

ALFENAS, A.C.; ZAUZA, E.A.V.; MAFIA, R.G.; ASSIS, T.F. Clonagem e doenças do eucalipto. 2nd.ed. Viçosa: Universidade Federal de Viçosa, 2009. 500p.

BLACKMAN, R.L.; EASTOP, V.F. Aphids on the world's herbaceous plants and shrubs. The aphids, John Wiley \& Sons with the Natural History Museum, London, v.2, p.1025-1439, 2006.

CARDOSO, J.T.Biologia e capacidade de consumo de insetos predadores do pulgão-do-pinus Cinara spp. (Homoptera: Aphididae). 2001.55 f. Dissertação (Mestrado em Ciências Biológicas) - Setor de Ciências Biológicas, Universidade Federal do Paraná, Curitiba, 2001.

CASTRO, B.M.C.; SOARES, M.A.; ANDRADE JÚNIOR, V.C.; PIRES, E.M. Batata-doce (Ipomoea batatas (L.) Lam.): um novo hospedeiro para Brevicoryne brassicae (L.) e Myzus persicae (Sulzer) (Hemiptera: Aphididae). Comunicata Scientiae, v.4, p.220-223, 2013.

CLARK, R.B. Characterization of phosphatase of intact maize roots. Journal of Agricultural and Food Chemistry, v.23, p.458-460, 1975.

GALLO, D.; NAKANO, O.; SILVEIRA NETO, S.; CARVALHO, R.P.L.; BATISTA, G.C.; BERTI FILHO, E.; PARRA, J.R.P.; ZUCCHI, R.A.; ALVES, S.B.; VENDRAMIM, J.D.; MARCHINI, L.C.; LOPES, J.R.S.; OMOTO, C. Manual de Entomologia Agrícola. Piracicaba: Ceres, 2002. 920p.
LEITE, G.L.D.; PICANÇO, M.; ZANUNCIO, J.C.; MOREIRA, M.D.; JHAM, G.N. Hosting capacity of horticultural plants for insect pests in Brazil. Chilean Journal of Agricultural Research, v.3, p.383-289, 2011.

MENEZES, C.W.G.; SOARES, M.A.; ASSIS JUNIOR, S.L.; FONSECA, A.J.; PIRES, E.M.; SANTOS, J.B. Novos insetos sugadores (Hemiptera) atacando Eucalyptus cloeziana (Myrtaceae) em Minas Gerais, Brasil. EntomoBrasilis, Vassouras, v.5, p.246248, 2012.

PEÑA-MARTINES, R. Identificación de afidos de importancia agrícola. In: URIAS, M.C.; RODRIGUES, M.R.; Alejandre, A.T. (Eds.). Afídos como vectores de virus en México. México: Centro de Fitopatología, 1992. 135p.

QUEIROZ, D.L.; RODRÍGUEZ FERNANDES, J.I.; ZANÚNCIO, J.C.; SANTOS, G.P. Pragas em viveiro de eucalipto. In: WENDLING, I.; DUTRA, L.F. (Orgs.). Produção de mudas de eucalipto. Colombo: Embrapa Florestas, 2010. v.1, p.139-184.

TARIQ, M.; WRIGHT, D.J.; ROSSITER, J.T.; STALEY, J.T. Aphids in a changing world: testing the plant stress, plant vigour and pulsed stress hypotheses. Agricultural and Forest Entomology, v. 14, p.177-185, 2012. 